\title{
Leishmania (infantum) chagasi in canine urinary sediment
}

\author{
Leishmania (infantum) chagasi em sedimento urinário canino
}

Ivete Lopes de Mendonça ${ }^{1 *}$; Joilson Ferreira Batista ${ }^{2}$; Leucio Camara Alves ${ }^{3}$

${ }^{1}$ Department of Veterinary Science and Surgery, Center for Agrarian Sciences, Federal University of Piauí - UFPI, Teresina, PI, Brazil

${ }^{2}$ Post-Graduate Program in Animal Science, Federal University of Piauí - UFPI, Teresina, PI, Brazil

${ }^{3}$ Department of Veterinary Medicine, Rural Federal University of Pernambuco - UFRPE, Recife, PE, Brazil

Received August 8, 2014

Accepted October 1, 2014

\begin{abstract}
Canine visceral leishmaniasis (CVL) is difficult to diagnosis, mainly due to the presence of asymptomatic animals, the diversity of clinical symptoms and the difficulty in obtaining diagnostic evidence of high sensitivity and specificity. The purpose of this study was to diagnose CVL in urinary sediment of 70 dogs of different breeds, sexes and ages from the veterinary hospital of the Federal University of Piauí and Zoonosis Control Center of Teresina, Brazil. The serological tests were TR DPP ${ }^{\circledR}$ for CVL and enzyme-linked immunosorbent assay (ELISA) for CVL, parasitological exams of bone marrow and lymph nodes and urine sediment cultures. Leishmania was detected in the bone marrow and/or lymph node of $61.0 \%$ of the animals (43/70), and urine sediment culture was positive in $9.30 \%(4 / 43)$ of these animals. In the serological exams, 70.0\% (49/70) were reactive using the DPP and 78.2\% (55/70) were reactive using ELISA. The goal of this study was to diagnose the presence of $L$. (infantum) chagasi in a culture of urinary sediment.
\end{abstract}

Keywords: Leishmania, urine, dogs, CVL, TR DPP ${ }^{\circledR}$.

\section{Resumo}

A leishmaniose visceral canina (LVC) é uma doença de difícil diagnóstico. Principalmente devido à presença de animais assintomáticos, a diversidade da sintomatologia clínica apresentada e também pela dificuldade em se obter uma prova diagnóstica que reúna alta sensibilidade e especificidade. O objetivo deste trabalho foi relatar a presença de L. (infantum) chagasi em meio de cultura, utilizando-se sedimento urinário. Foram utilizados neste experimento, 70 cáes provenientes do Hospital Veterinário Universitário da Universidade Federal do Piauí e do Centro de Controle de Zoonoses de Teresina, com raça, sexo e idade variada. Foram realizados exames sorológicos: TR DPP ${ }^{\circledR}$ Leishmaniose Visceral Canina (DPP) e Ensaio Imunoenzimático Leishmaniose Visceral Canina (ELISA), exames parasitológicos de amostras de medula e/ou linfonodo e cultura de sedimento urinário. Em 61,0\% (43/70) dos animais estudados, observou-se presença de Leishmania em medula e/ou linfonodo, e destes 9,30\% (4/43) foram positivos na cultura de sedimento urinário. Nos exames sorológicos, 70,0\% (49/70) dos animais apresentavam-se reativos no DPP e 78,2\% (55/70) no ELISA. Pode-se concluir, neste estudo, que é possível diagnosticar a LVC por meio da cultura de sedimento urinário.

Palavras-chave: Leishmania, urina, cáes, LVC, TR DPP ${ }^{\circledR}$.

\section{Introduction}

Depending on their individual immunological status, dogs naturally infected with Leishmania (infantum) chagasi can exhibit three clinical manifestations: asymptomatic, oligosymptomatic and polysymptomatic (GIUNCHETTI et al., 2006; QUEIROZ et al., 2010). Canine visceral leishmaniasis (CVL) is difficult to diagnosis due to this diversity of clinical symptoms and the difficulty in obtaining highly sensitive and specific diagnostic

*Corresponding author: Ivete Lopes de Mendonça, Departamento de Clínica e Cirurgia Veterinária, Centro de Ciências Agrárias - CCA, Universidade Federal do Piauí - UFPI, Campus Ministro Petrônio Portela, Bairro Ininga, CEP 15385-000, Teresina, PI, Brasil, e-mail: ivetemendonca@ig.com.br evidence (CASTRO et al., 2012). Moreover, direct parasitological tests are invasive, time-consuming and can produce false-negative and false-positive results. Conventional serological tests are limited due to cross-reactions with other parasitological diseases. Thus, a number of studies have discussed polymerase chain reaction (PCR) and immunoassays based on the use of recombinants to enhance the sensitivity and specificity of the diagnosis of CVL (BENSOUSSAN et al., 2006; GOMES et al., 2008). Invasive methods have been used for the diagnosis of this disease based on clinical samples, such as aspirates of bone marrow, spleen tissue and lymph nodes (GOMES et al., 2008), but such methods are distressing for animals. 
This study aimed to detect the presence of $L$. (infantum) chagasi in a culture of urinary sediment.

\section{Methods}

\section{Animals}

The experiments were performed on blood and urine samples from 10 dogs from the veterinary hospital of the Federal University of Piauí and 60 dogs captured by the Zoonosis Control Center in the city of Teresina, state of Piauí, Brazil. The animals were selected based on random sampling and were kept at the kennel of the university until the biological materials were collected.

All the animals were clinically examined to check for the presence or absence of clinical signs.

\section{Parasitological diagnosis of CVL}

Bone marrow aspiration was performed on the sternum in all the animals, using a lidocaine $2 \%$ solution for local anesthesia. Bone marrow aspirates were collected with a $20 \mathrm{~mL}$ syringe and 40x12 needle and popliteal lymph node aspirates with a $10 \mathrm{~mL}$ syringe and $25 \times 7$ needle.

The samples were inoculated in NNN culture medium enriched with Schneider's medium. Readings to identify promastigote forms of Leishmania sp. were performed 5, 8, 10 and 15 days after inoculation.

\section{Serological tests}

A volume of $10 \mathrm{~mL}$ of blood was drawn from the jugular vein into vacuum tubes without anticoagulant for the acquisition of serum. The serological tests were TR DPP ${ }^{\circledR}$ for CVL and enzymelinked immunosorbent assay (ELISA) for CVL. Both tests were performed using the Bio-Manguinhos/Fiocruz kit, following the manufacturer's recommendations.

\section{Urinary sediment}

To avoid pain and bacterial contamination, the urine samples were collected though cystocentesis, with volumes ranging from 6 to $80 \mathrm{~mL}$. The urine was immediately centrifuged for 20 minutes at $2218 \mathrm{~g}$. The entire sediment was inoculated in NNN culture medium enriched with Schneider's medium. Readings to determine promastigote forms of Leishmania were performed 5, 8,10 and 15 days after inoculation.

This study was approved by the Animal Experimentation Ethics Committee of the Federal University of Piauí (Brazil), under Process no. 022/13.

\section{Results and Discussion}

L. (infantum) chagasi was detected in $61.4 \%(43 / 70)$ in bone marrow and $67.4 \%(29 / 43)$ in lymph nodes, while $76.7 \%$ (33/43) and $48.8 \%(21 / 43)$ of the animals showed amastigote forms of L. (infantum) chagasi in bone marrow and popliteal lymph node, respectively. The urine sediment culture tested positive for $9.3 \%$ (4/43) of the dogs. In the serological exams, 70.0\% (49/70) showed reactivity in the TR DPP ${ }^{\circledR}$ and $78.2 \%(55 / 70)$ in the ELISA tests. The animals whose urinary sediments tested positive were also positive using the DPP, ELISA and bone marrow and lymph node cultures (Table 1).

The presence of the parasite in urinary sediment may be due to glomerulonephritis, interstitial nephritis and the deposition of immune complexes, which can lead to decreased peritubular perfusion, with the consequent passage of macromolecules or Leishmania sp. (MANNA et al., 2008). The viability of Leishmania sp. in the urinary sediment of dogs was first reported by Riera $\&$ Valladares (1996), who investigated the presence of the parasite in the urine and semen of six dogs experimentally infected with Leishmania infantum, two of which (33.3\%) were positive in the urine culture and one (16.7\%) in the semen culture.

Mebrahtu et al. (1993) found Leishmania sp. in the urine of $5.3 \%$ (2/38) of human patients with visceral leishmaniasis (VL) in Kenya, using NNN culture medium enriched with Schneider's medium. The authors also reported that contamination of the urinary sediment, with bacteria, yeast, or fungus, may have contributed to the low prevalence of the parasite in urine, as $18.4 \%$ of the samples had been contaminated. In this study, only $5.7 \%$ of the urine sediment cultures were contaminated, with bacteria end/or fungus, probably due to the sample handling procedures employed here.

Most parasitological diagnostic methods for CVL are invasive; hence, researchers are seeking a less invasive method that can contribute to the routine diagnosis of VL. Cystocentesis can be adapted easily for this purpose, since it is a less invasive method which does not require special equipment or sophisticated technology.

Table 1. Serological and parasitological results of dogs showing the presence of Leishmania sp. in urine sediment, from Veterinary Hospital of the Federal University and Zoonoses Control Center, in the Terezina city of Piauí, Brazil.

\begin{tabular}{cccccc}
\hline \multirow{2}{*}{ Animal } & \multicolumn{2}{c}{ Serology } & & \multicolumn{2}{c}{ Parasitology } \\
\cline { 2 - 5 } & TR DPP & ELISA & Marrow & Lymph node & USC \\
\hline I & Reactive & Reactive & Positive & Positive & Positive \\
II & Reactive & Reactive & Positive & Positive & Positive \\
III & Reactive & Reactive & Positive & Positive & Positive \\
IV & Reactive & Reactive & Positive & -
\end{tabular}

DPP - Canine visceral leishmaniasis TR DPP ${ }^{\circledR}$; ELISA - Canine visceral leishmaniasis enzyme-linked immunosorbent assay; USC - urine sediment culture. 


\section{Conclusion}

In conclusion, this study demonstrated the possibility of isolating $L$. (infantum) chagasi in a culture medium from dog urine sediment.

\section{Acknowledgments}

The authors are indebted to the Zoonosis Control Center of Teresina and the owners of sick dogs for the donation of the animals used in this study.

\section{References}

Bensoussan E, Nasereddin A, Jonas F, Schnur LF, Jaffe CL. Comparison of PCR assays for diagnosis of cutaneous leishmaniasis. J Clin Microbiol 2006; 44(4): 1435-1439. http://dx.doi.org/10.1128/JCM.44.4.14351439.2006. PMid: 16597873

Castro IP, Sousa MVC, Magalhães GM, Mundim AV, Noleto PG, Paula $\mathrm{MBC}$, et al. Perfil hepático e protéico em cáes com leishmaniose visceral. Biosci J 2012; 28(5): 799-804.

Giunchetti RC, Mayrink W, Genaro O, Carneiro CM, Corrêa-Oliveira $\mathrm{R}$, Martins-Filho OA, et al. Relationship between canine visceral leishmaniosis and the Leishmania (Leishmania) chagasi burden in dermal inflammatory foci. J Comp Pathol 2006; 135(2-3): 100-107. http:// dx.doi.org/10.1016/j.jcpa.2006.06.005. PMid:16959259

Gomes YM, Paiva Cavalcanti M, Lira RA, Abath FG, Alves LC. Diagnosis of canine visceral leishmaniasis: biotechnological advances. Vet J2008; 175(1): 45-52. http://dx.doi.org/10.1016/j.tvjl.2006.10.019. PMid:17150389

Manna L, Reale S, Picillo E, Vitale F, Gravino AE. Urine sampling for real-time polymerase chain reaction based diagnosis of canine leishmaniasis. J Vet Diagn Invest 2008; 20(1): 64-67. http://dx.doi. org/10.1177/104063870802000112. PMid:18182511

Mebrahtu YB, Hendricks LD, Oster CN, Lawyer PG, Perkins PV, Pamba $\mathrm{H}$, et al. Leishmania donovani parasites in the nasal secretions, tonsillopharyngeal mucosa, and urine centrifugates of visceral leishmaniasis patients in Kenya. Am J Trop Med Hyg 1993; 48(4): 530 535. PMid:8480861.

Queiroz NM, de Assis J, Oliveira TMFS, Machado RZ, Nunes CM, Starke-Buzetti WA. Diagnóstico da Leishmaniose Visceral Canina pelas técnicas de imunoistoquímica e PCR em tecidos cutâneos em associação com a RIFI e ELISA-teste. Rev Bras Parasitol Vet 2010; 19(1): 32-38. http://dx.doi.org/10.4322/rbpv.01901006. PMid:20385057

Riera C, Valladares JE. Viable Leishmania infantum in urine and semen in experimentally infected dogs. Parasitol Today 1996; 12(10): 412. http:// dx.doi.org/10.1016/0169-4758(96)90062-9. PMid:15275299 